\title{
What is German Protestant Theology Saying About the Non- Christian Religions?
}

\author{
Rev. Paul K n it te r, S. V. D., Dr. Theol. Des., \\ Catholic Theological Union \\ 5401 South Cornell Ave., Chicago, Ill. 60615
}

The following study hopes to serve as a stimulus to an ecumenical Christian Theology of the Religions by asking whether and how one segment of that theology is confronting the "other religions". We will offer - from a "Catholic viewpoint " - a survey of present-day German Protestant attitudes towards the religions and weigh how these attitudes are clarifying the questions which are essential to a well-defined theology of the non-Christian religious world and to a theological dialogue with this world: What, if any, role do the religions play in the »history of salvation «? Can we speak of a genuine divine presence or revelation within the religions? And can this revelation be the basis for a faith-encounter with the Deity - i. e., for the attainment of salvation? - Or, more generally: must the Christian's attitude toward and encounter with other religions be basically positive or negative? And why? - What stance do contemporary German-speaking Protestant theologians take to all these questions? ${ }^{1}$

\section{Present State of German-Protestant Theology of Religions}

1. The lack of a formed and integrated Theology of the Non-Christian Religions among Protestant thinkers is painfully evident, still today. This is admitted as a "nostra culpa « by numerous Protestant theologians.

1 This article incorporates the "verification chapter* to the author's doctoral dissertation, A Case study for a Protestant Theology of the Religions: Paul Althaus (Marburg-soon to appear in the Marburger Theologische Studien). This case study traces Althaus' attempts to establish a $\gg$ middle path $*$ between the extreme views of Troeltsch and Barth concerning the religions. On the basis of his $»$ Uroffenbarungslehrea, Althaus can conclude, explicitly and implicitly, to surprisingly positive judgments on the religions; but in the light of his doctrine of justification these judgments are obfuscated and even retracted. An uncomfortable tension results. In the final analysis, the Reformational principles of $x$ sola fide* and *solus Christus force Althaus to draw a quite negative stand to the religions; at the most they can be only a "praeparatio negativa * for salvation in Christ. - Is this the final verdict which every Protestant theologian must voice if he wishes to remain faithful to the Reformers' doctrine of justification? Or, more precisely: have present-day German-speaking Protestant theologians gone beyond this basically negative verdict? 
Die Forderung einer *Theologie der Religion«... (i. e., wie das Verhältnis Christentum und Religionen grundsätzlich theologisch bestimmt werden kann und muß) ... ist in den letzten 20 Jahren immer wieder erhoben worden. Aber es ist auch in der Gegenwart eigentlich erstaunlich wenig getan, um diese Dinge zu klären. ${ }^{2}$

Im Gegensatz zu der allein quantitativ imponierenden Aufnahme dieser Herausforderung durch die katholische Theologie seit Karl Rahner mit ihrer beachtlichen inneren Geschlossenheit erscheint - von rühmlichen Ausnahmen abgesehen - die Reaktion der protestantischen Theologie zögernd und uneinheitlich, gedanklich oft vage oder spekulativ. ${ }^{3}$

... while German theology has taken modern atheism seriously, there is little sign of its taking seriously the fact of other religions than Christianity; this failure is of even greater significance for the substance of theology itself. 4

It is also commonly admitted that one of the most weighty reasons for this lack of concern for the religions is the inescapable influence of Karl Barth. His critique of religions as basically opposed to revelation $^{40}$ - coupled with Bonhoeffer's widely accepted insistence on a "religionloses Christentum " - casts a very suspicious shadow over all religious phenomena. One may rightly point out that this condemnation of religion is greatly mellowed and clarified when we remember that it was intended also - or better, primarily - for the Christian religion. ${ }^{5}$ Yet the fact remains: when such a concept is part of a study of the "other religions " it obstructs any real encounter with them and colors them as, essentially, irrelevant for theology. To those who argue that this is a misuse of Barth's and Bonhoeffer's concept of religion, we may answer that the de facto situation of Protestant theology of the religions proves that this has been its effects. ${ }^{6}$

2 C. H. Ratschow, "Die Religionen und das Christentum\&, Der dristliche Glaube und die Religionen, hrsg. von C. H. Ratschow (Berlin, 1967), pp. 97-98.

3 P. Beyerhaus, »Zur Theologie der Religionen im Protestantismus«, KuD, 15 (1969) 100.

4 Maurice Wiles. Review of H. Zahrnt, The Question of God (London, 1969) Religious Studies, 5. 2.1969, p. 272, quoted in J. A. Veitch, "The Case for a Theology of Religions*, SJTH, 24 (1971) 419. - H. W. Gensichen »Die Herausforderung der protestantischen Mission durch das Zwcite Vatikanische Konzil«, MdKI, 17 (1966) 86; K. Nürnberger, Glaube und Religion bei Karl Barth (Diss. Marburg, 1967), pp. 11-12, 134; P. Rossano, "Le Religioni Non Christiane nella Storia della Salvezza. Rassegna delle Posizioni teologiche attuali $\alpha$, La Scuola Cattolica, 1965, supplemento 2, p. 11; U. Mann, Theogonische Tage (Stuttgart, 1970), pp. 130-133, 154.

4a Cf. P. Knitter, Christomonism in Karl Barth's Evaluation of the Non-Christian Religions*, NZSTh 13 (1971) 99-121.

5 For such a reminder, cf. Hans Strauß, "Krisis der Religion oder Kritik der Religionen?!?», Parrhesia, Karl Barth zum 80. Geburtstag (Zürich, 1966), pp. 305 bis 320.

- For Barth's negative influence on Protestant attitudes towards the religions, cf.: Ratschow, „Die Religionen*, p. 100; G. Rosenkranz, Der christliche Glaube ange- 
2. And yet we must also point out that attitudes of German Protestant theology towards the religions have developed and changed since Barth unleashed his apocalyptic "No " to religion and since it took on added resonance - mainly through the works of Hendrik Kraemer - in the third World Missionary Conference in Tambaram in 1938. Even though the majority of theologians still do not give the religions sufficient attention or significance, there are a number of Protestant thinkers (and their ranks seem to be happily increasing) who - stimulated by the example of the World Council of Churches ${ }^{7}$ and by the new Catholic theology of the Religions ${ }^{8}$ - show a growing awareness that the nonChristian religious world cannot be ignored, and that it does have a meaning for Christian theology.

To give our general survey of this new awareness better orientation and more precision, we shall first outline the views of three systematic theologians - Hans Georg Fritzsche, Carl Heinz Ratschow, and Wolfhart Pannenberg - who, we feel, have dealt with the religions more extensively and who represent the general tendencies within German Protestant Theology. Under these theologians we will then give examples of what seems to be the "opinio communis « of systematic theologians and then of mission theologians.

\section{H. G. Fritzsche ${ }^{9}$ - Example of Reformed Tendency}

1. Fritzsche's treatment of the non-Christian religions in his "Lehrbuch der Dogmatik «10 is, at first sight, quite positive. Reviewing modern history of Protestant thought, Fritzsche distinguishes three different

sichts der Weltreligionen (Bern, 1967), p. 218; Nürnberger, p. 134; W. Bühlmann, -Die Theologie der Nichtchristlichen Religionen als ökumenisches Problem«, Aus Freiheit in der Begegnung. hrsg. von J. L. Leuba und H. Stirnimann (Frankfurt, 1969), p. 456; C. F. Hallencreutz, New Approaches to Men of Other Faiths. 1938-1968. A theological discussion (Geneva, 1970), p. 27: W. H. van de Pol, Die Zukunft von Kirche und Christentum (Wien, 1970), pp. 104-108; P. Knitter, - Paul Althaus: An Attempt at a Protestant Theology of the Non-Christian Religions*, Verbum SVD, 11 (1970) 214-215.

7 Especially as voiced in the New Delhi meetings, 1961. For an excellent presentation of the development in the WCC attitudes towards the religions, cf. the Münster Dissertation of Gerard Vallee, Eine ökumenische Diskussion über die inter-religiöse Begegnung - Von Tambaram nach Uppsala 1938-1968; also his article $\rightarrow$ Die Zukunft des ökumenischen Dialogs mit Nicht-Christen *, Una Sancta 26 (1971) 166-173; cf. also Living Faiths and the Ecumenical Movement, S. J. Samartha, ed., Geneva, 1971.

8 Particularly under the lead of Karl Rahner; cf. his pioneering study, „Christentum und die nichtchristlichen Religionen *, Schriften V, pp. 136-158.

- Professor of Systematic Theology at Humboldt University, Berlin.

10 \$ Christlicher Glaube und ,Religion`«, in Lebrbuch der Dogmatik. Teil I (Göttingen, 1964), pp. 207-278. 
attitudes towards the religions: a) the dogmatic, which boils down to a rejection of the non-Christian religious world, as seen especially in Barth's works; b) the bistorical, which ends up denying any real difference between Christianity and the religions, as represented by Troeltsch; and c) the practical, which tries to recognize the positive values of the religions and thus establish a true encounter with them. Fritzsche declares that his own way is that of the practical approach, seeking "einen mittleren Standpunkt zwischen Troeltsch und Barth « and using the »dogmatic « and the "historical « positions as "correctives «. ${ }^{11}$

Fritzsche urges his fellow theologians to distinguish the "good from the bad " in the religions. Even though there may be much that is rooted in sin, one must be able to separate the plant from the roots - and make use of it. The "Vielfalt des empirischen Erscheinungsbildes" of the religions contains many valuable elements which provide the basis for a positive encounter with them. "In den Religionen ist ein echtes und ernst zu nehmendes Fragen nach Gott und Erlösung lebendig, an das die christliche Verkündigung anknüpfen kann und muß. « ${ }^{\mathbf{1 2}}$

And when he goes into an empirical or phenomenological description of these positive elements, he seems to imply even more than «questions*. He sums up what the religions and Christianity have in common under three general headings: a) •Gemeinsame Themene, i. e., "Gottheit, Erlösung, sittliche Kraft, Weltanschauungsfragen «. b) »Gemeinsame Fragestellungen bzw. Voraussetzungen *; by this he means the experience of the contradictions and distortions of human existence which point man in a direction outside himself for solutions. c) 》Gemeinsame Antworten (!) bzw. Einzelaussagen «, and here he has some particularly positive words for Mahayana Buddhism's insights and *answers* concerning faith based on sola gratia et sola fider. ${ }^{13}$

2. And yet after (and even within) this quite positive commentary on the world of religions, Fritzsche sets up an interpretation of the "solus Christus" which empties them of any real value in themselves, i. e., before their meeting with Christ. Although he tries to find a middle way between Troeltsch and Barth, he ends up much closer to Barth - even, we feel, still within Barth's position. For God has touched the world only in Christ; this means that only on this christologic mathematical point are both revelation and salvation to be found. The positive content of the religions can never be termed a revelation; it does not make God known to the non-Christians. Theologically, the most that the religions can contain is a "resonance" for Christian revelation - but a resonance which can be heard "nur von der Bibel her; ursprünglich aus Natur und Geschichte heraus gibt es keine Offenbarung Gottes «. ${ }^{14}$ What the religions contain is »nur die Möglichkeit von Offen-

11 Ibid., pp. 208-209, 223.

12 Ibid., p. 209, also 222-223.

13 Ibid., pp. 226-227.

14 Ibid., p. 296. 
barung " - a possibility which can be realized only in the "Christusereignis ${ }^{15}{ }^{15}$ "Gott ist durchaus in der Natur erfahrbar, aber nicht aus ihr heraus. « ${ }^{16}$

On the basis of this exclusive understanding of the "solus Christus «, Fritzsche's back-tracking on the positive phenomenological values of the religions becomes quite drastic and confusing. All the "common elements « between Christianity and the religions turn out to be more opposed than similar.

Fritzsche lists these differences, again under three headings: a) the Verständnis Gottes, which consists of a twofold opposition: "Entweder wird ,Gottc als leeres Prinzip und damit als unpersönliches Es verstanden, oder sein Personsein ist mit ganz anderen Zügen ausgestattet als denjenigen des in Jesus Christus offenbarten einen Gottes.a b) in the Streben nach Erlösung, in which Fritzsche argues that the religions do not really understand the nature of justification and corrupt it by seeking redemption "vom Ich« or * von der Existenz als solcher instead of accepting from God a liberation from sin which enables them to find their responsible selves. c) in etbischen und praktischen Fragen, where Fritzsche's verdict seems even more »preordained*. He states categorically that while $*$ Das Evangelium befreit zu echter Sachlichkeit und macht die Kräfte frei für die eigentliche Arbeit des Tages«, the religions waste their efforts (»leerlaufen und heißlaufen «!) *in sinnlosen kultischen Anstrengungen sowie in der Sicherungshysterie der Opfermentalität«. ${ }^{17}$

"Der entscheidende Gegensatz « which is contained in all these differences and which is illustrated especially in "den ostasiatischen Erlösungsreligionen " is that because the religions do not have Christ they are works of the Law. Man is trying to fashion his salvation by himself; he is dealing only with himself. Fritzsche expresses this by calling these religions "psychologische Religionen ". While Christianity, »die Religion der Wahrheit ", accepts its redemption as a bistorical, divine fact and as an "objektive Realität «, the religions search for a man-made psychological redemption. Fritzsche therefore enunciates the final and separating difference between Christianity and the religions as: "Theozentrismus und Anthropozentrismus... Erlösung und Selbsterlösung " ${ }^{18}$ These differences are clearly demanded by his understanding of justification as limited to the historical reality of Christ. The religions remain, as Barth proclaimed, works of sin.

The final relation, therefore, between Christianity and the religions, is overpoweringly negative: "Zusammenfassend kann man sagen, daß es die Losung, 'Christus des Gesetzes Ender (Röm. 10,4) ist, womit in einem Aufhebung der Sünde, Aufhebung der Religion und Aufhebung des Aberglaubens gegeben sind. ${ }^{\mathbf{1 9}}$

\footnotetext{
15 Ibid., p. 297.

16 Ibid., p. 301.

17 Ibid., pp. 247-253

18 Ibid., pp. 255-257.

19 Ibid., p. 222.
} 
3. One must ask: What is left of Fritzsche's "practical and more positive middle way «? Whatever positive content might be in the religions is really and effectively not there until confronted with Christ's revelation; Fritzsche's "von Christus her ", like Barth's, is absolute. And then, when the actual confrontation takes place, all that the religions seem to be able to offer are distorted and sinfully-misused longing; this, apparently, is the essence of their "Anliegen « and "Anknüpfungspunkte" upon which Fritzsche seeks to establish an encounter and dialogue. ${ }^{20}$ In the end, the religions offer questions and only questions; they constitute only a negative preparation for Christ.

\section{H. Ratschow - Example of Lutheran Tendency ${ }^{21}$}

1. Few present-day German Protestant theologians can rival C. $\mathrm{H}$. Ratschow in the open-mindedness and freshness of his approach to the non-Christian religions. He sees the long-neglected problem of the religions and resolutely attempts the necessary and perhaps unexplored steps in trying to solve it. His efforts have been called »bei weitem die leistungsfähigste " in arriving at a theology of the religions. ${ }^{22}$ What really seems to give these efforts their originality and their boldness is Ratschow's extensive knowledge of the religions themselves. He insists that the theologian must know not only his own faith but also the religions themselves before he can pass judgment! Theologians have produced too much abstract musing about "religion «, forgetting: "Die Religion gibt es nur in den Religionen. ${ }^{23}$

2. Arguing as both theologian and historian of religions, then, Ratschow concludes to a real and active presence of God within the religions. In varying terminology, he describes this presence as the "zentrale Geschehen in den Religionen: Das ist der Gott! Sein Hervortreten, Seine Präsenz, Sein Heil und Seine Versöhnung sind das Subjekt und der Kern allen religiösen Tuns. Das erste Bewegende in allen Religionen ist die Unwiderstehlichkeit des Gottes! «24 The terms which Rat-

20 Ibid., p. 258 , cf. pp. $259-267$.

21 Ratschow has frequently been referred to as a representative of the Lutheran attitude towards the religious world. Cf. Beyerhaus, «Zur Theologie*, pp. 98-99; K. Lüthi, «Ist Christentum Religion?*, Wort und Wabrbeit, 24 (1969), 105-106. For a concise characterization of Ratschow's theological method, cf. K. Nürnberger, "Systematisch-theologische Lösungsversuche zum Problem der anderen Religionen und ihre missions-methodischen Konsequenzen *, NZSTh, 12 (1970) 30-37.

22 Nürnberger, "Systematisch $\alpha$, p. 37; Nürnberger here is comparing Ratschow especially with Barth's and Bultmann's views of the religions.

${ }^{23}$ Ratschow, „Die Religionen*, pp. 89, 94-95.

24 Ibid., p. 105. 
schow seems to prefer are »das Hervortreten Gottes« or his »Eindrücklichkeit « in the religions. ${ }^{25}$

$\mathrm{He}$ argues that this divine stepping-forth takes place in two principal forms: Through his Heilshandeln God is experienced in a heilvollen Einmal, in dem der verehrte Gott zum ersten Male oder ein für alle Mal hervortrat und handelte oder sprach. It unveils both the possibility and goal of this present life as well as its limitations and negation. ${ }^{20}$ Then there is God's stepping-forth in his Weltbandeln - als das Transparentwerden des Augenblicks oder der Situation «. Here man experiences the godhead as the reality behind the world in general and his particular moment. Experiencing God in the present, he can thus confront the future. ${ }^{27}$

Ratschow is adverse to calling this *Hervortreten Gottes* an «Offenbarung* or *revelatio generalis or bloßer notitia dei $*$. The reason why he shuns such terminology both in theology and in comparative religions is that it is *irreführend and $*$ nichtssagend «: it does not bring out the real and special experience of God within this process and implies that man takes cognitional possession of God instead of encountering him. ${ }^{28}$ Ratschow insists that man's encounter with God in the religions is God's work - in Catholic terminology, a supernatural occurrance. It cannot be deduced » aus einer gemeinsamen anthropologischen Grundlage ${ }^{29}$ or from the religiösen ... a priori's seines (man's) snatürlichen menschlichen Daseins«. ${ }^{30}$ Ratschow feels that this is religions-wissenschaftlich unbestreitbar $\mathbf{*}^{31}$ it is attested to in the beliefs of the religions themselves and especially in the phenomenological facts of the $*$ Kontingenz und überschaubaren Spontaneität im Hervortreten der Gottheit ${ }^{32}$ and the xeminent großen Verschiedenheit der Götter $*$. All this points out a unique, individual divine action. ${ }^{33}$

3. Ratschow holds not only that all religions are alive with the divine (not man-made) presence of God, but »... daß alle Religionen als Religionen Erlösungs-Religionen sind «. ${ }^{34}$

The basis for this assertion is what Ratschow calls die Ausgangssituation von Religion - for the non-Christian and Christian religion: man's *Angefochtenheit *. Man experiences God but cannot reconcile this experience with the contradictoriness and apparent meaninglessness of himself and the world. Thus he clashes with the »undurchschaubaren Ambivalenz* of God and the world, which Ratschow describes in

25 Ibid., p. 105; cf. also Die Möglichkeit des Dialogs angesichts des Anspruchs der Religionen*, Evangelisches Missions-Jabrbuch, 1970, p. 111; also, Glaube und Erkenntnis* Anstöße. Berichte aus der Arbeit der Evangelischen Akademie Hofgeismar (1968, Nr. 5/6), pp. 153-156.

26 Die Religionen*, pp. 107-108.

27 Ibid., p. 112; cf. also Ratschow, Das Heilshandeln und das Welthandeln Gottes«, NZSTh, 1 (1959) 25-80. In his compact work, Gott existiert, Ratschow goes into the metaphysical basis for this $\gg$ Welthandeln $*$. It is part of the unity of essence and existence in God. God's essence is his »de facto in der Welt Sein *, his $\gg$ Wirklichkeit «. (Cf. pp. 61-75, esp. 61-70.)

28 Die Religionen «, pp. 107, 115.

29 Die Möglichkeit«, p. 112.

so Die Religionen «, p. 125, cf. also pp. 114-115.

31 Ibid., p. 126.

32 -Die Möglichkeit«, p. 112.

33 Die Religionen «, pp. 115-116; cf. also Nürnberger, »Systematisch«, p. 34.

34 Die Möglichkeit«, p. 133, emphasis mine; cf. also Ratschow, Magie und Religion (Gütersloh, 1955), p. 97. 
various contexts as the clash between $\star$ Zorn und Liebe*. Ordnungsmacht und Ver-

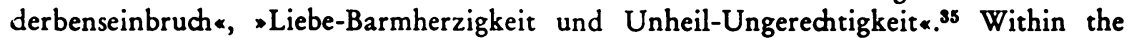
s ambivalence of God* the non-Christians experience and come to a knowledge of the

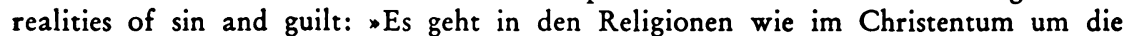
Erlösung des Menschen und um die Erlösung der Welt aus der Gefangenschaft des Todes und der hinter ihm stehenden Grundschuld des Menschen ... Die Anthropologie der nichtchristlichen Religionen wei $\beta$ um die mit dem Menschen gesetzte Unausweichlichkeit von Schuld... Die Erlösungsbedürftigkeit des Menschen wie der Welt ist das Thema aller Religionen. ${ }^{36}$ The homo religiosus* experiences a Preisgegebenheit als Gottes Zorn zum Todesschrecken $\star^{37}$

This experience of ambivalence, however, is not the essence of the religions' insight into redemption. "Die Grundeinsicht der Religionen als Erlösungsreligionen besteht in der Erkenntnis: >Nur durch das Sterben bleibt das Leben wach $"{ }^{38}$ Ratschow is convinced that the "common denominator " of all religions, expressed in a multitude of forms, is the realization that "vivificatio " can come only through "mortificatio . Man in his religions declares that he must give way to God; in practicing his religion, he tries to do just this! "Die Lösungen des Weges der Religions-Ưbung zeigen überall den Charakter, daß der Mensch sich aufzugeben hat, um dem Gotte und seinem Willen Raum zu geben. In der Religion-Ưbung geht es um ein Sterben. Dieses Sterben bringt das wahre Leben! Das ist die einheitliche Struktur des Vorganges, den wir in den Religionen sehen. ${ }^{39}$

4. On the basis of this theological-phenomenological understanding of the religions, Ratschow concludes to what has been called meine frappante und lückenlose Parallelität " between Christian and nonChristian faiths. ${ }^{40}$ The same God gives himself to man's experience and knowledge - always in different forms and processes. And there is the seeking after life through death. In all this there is a "von Gott stammende Wahrheit ... die 'nicht fern vom Reiche Gottes` ist «. ${ }^{41}$ And therefore Ratschow points out the foundation for and necessity of a positive dialogue between Christianity and the religions. One of the clearest examples of such a dialogue - and one of the soundest supports for a "theology of the religions" - he find's in the historical dialogue with the religions which took place in both the Old and the New Testaments. The full content of such parallels have not, he feels, been fully seen or evaluated by Christian theology. ${ }^{42}$

35 Ratschow, Der angefochtene Glaube (Gütersloh, 1957), p. 279; „Die Religionen *, pp. 118-120, 123-124.

36 - Die Möglichkeit «, p. 113.

37 Der angefochtene Glaube, p. 260.

38 -Die Möglichkeit «, p. 115, emphasis mine.

30 „Die Religionen*, pp. 123-124, cf. also pp. 127-128.

10 Nürnberger, "Systematisch $*$, p. 33.

4 Die Möglichkeit «, p. 116.

2 Ibid. 
5. Ratschow's vision of the religions, then, is boldly positive. And yet, when he "draws the line " and points out the differences between the religions and Christianity - as every theologian must - certain perplexing questions arise. Ratschow stresses that despite and within »dieser weitreichenden Gemeinsamkeit der Religion und des Christentums" there is "eine ganz zentrale Trennung", "ein tiefer und sehr grundsätzlicher Unterschied ", elements which are »kontradiktorisch verschieden " and which bring about a "schlechthinnige Antithese ${ }^{43}$ These contradictory differences are contained within the doctrine of justification: "Die Selbstaufgabe des Menschen ist im Christentum dem Heil konsekutiv, in den Religionen aber konstitutiv.«»...daß den Religionen die mortificatio konstitutiv ist für die vivificatio, daß im Christentum aber die mortificatio der vivificatio konsekutiv folgt. " ${ }^{44}$ Simply: in the religions man tries to achieve salvation through his own works; in Christianity, he accepts it as a gift, "sola fide, sola gratia «. Ratschow implies: the religions of themselves cannot attain to a proper understanding of justification. That the reason for this position is rooted in the "solus Christus « is clear in one of his closing statements: "Der zureichende Grund für die Unterschiedenheit dieses Verhältnisses ist in der christologischen Überlegung zu finden. ${ }^{45}$

The basic difference between religions and Christianity would therefore seem to be that between Law and Gospel. In his Der Angefochtene Glaube Ratschow asserts this quite clearly: since the religions try to appease the wrath of God through observance of the Law, ". . . tragen alle Religionen den Charakter der Gesetzlichkeit . . . Uber diese Situation hinaus geht der homo religiosus den Weg, Gott durch Gesetzeswerke und Opfer zu versöhnen, sich also vor Gott gerecht zu machen... In den Religionen geht es um Selbstrechtfertigung durch Gesetzeserfüllung. Im Glauben geht es um Selbstaufgabe in Gesetzesnot. « ${ }^{46}$

That the religions do not and cannot understand the "sola fide", that they cannot break out of the borders of the "Law ", is the reason, we feel, why Ratschow has to severely restrict the clarity of God's

43 -Die Religionen*, pp. 128, 125; Der angefochtene Glaube, pp. 261, 280.

44 „Die Religionen «, pp. 126. 128.

45 -Die Religionen «, p. 128. Within his studies of the religions, however, Ratschow does not unfold this christological foundation.

46 Der angefochtene Glaube, pp. 260-261. In his later treatments of the religions, Ratschow modifies this category of Law-Gospel insofar as he adds that the - consecutive-constitutive-difference* does not allow weinen einfachen Gegensatz von Religion und Christentum als Gegensatz von Gesetz und Evangelium ( $*$ Die Religionen *, p. 126). The opposition is not *ausschließend . But this is only because also in der kirchlichen Erscheinungsform des Christentums * there is the constant tendency to make saving use of the Law; also in Christianity there is the same 
"Hervortreten « in the religions and has to impose his own "von Christus her". In Der Angefochtene Glaube Ratschow implies that in the preChristian realm, man cannot really understand his situation as an "Anfechtung " or his own sinfulness. We can speak of "Anfechtung * only from "einem Glaubensgeschehen ", only "unter Voraussetzung der Gottestaten im Alten und Neuen Testament...«47 "Es ist so, wie das Alte und das Neue Testament es bezeugen, daß ohne das Wort Gottes und das Gekommensein Jesu das peccatum gar nicht sichtbar wird. ${ }^{48}$ Therefore the religions cannot be considered as a "vor- oder außerchristlicher Bereich, der möglicherweise als Vorstufe oder Vorverständnis angesehen werden könnte «. That the process of "Anfechtung " is "in eminenter Weise erhellt « in the religions is something we can see only from the viewpoint of the Gospel. ${ }^{49}$ - This leads one to ask just how much of a "Gotteserfahrung " or of a "Grundeinsicht von Erlösung « ${ }^{50}$ can the religions really attain on their own, i. e., without the "von Christus her? «

6. It should be noted that Ratschow does not conclude from the "schlechthinnigen Antithese " and from the religions' character as Law that they are therefore works of sin and completely "heillos«. He does not condemn the religions. And yet if such a conclusion is not stated nor even implied, is it not contained within Ratschow's position that all religions seek salvation "constitutively " and therefore remain within the Law? Within the order of the Law, one cannot yet find salvation, even though one is being, negatively, prepared for it. Also, as soon as one tries to achieve salvation through his own works, i. e., "constitutively ", isn't he excluded from justification? Doesn't he fall into sin? Such questions, we feel, are not answered or sufficiently considered within Ratschow's position.

And it would seem that the reason why Ratschow must introduce such negative, contrasting lines into his assessment of the religions - the reason why the religions end up as only a negative preparation for the Gospel (in that they express questions but no real answers) stems implicitly from the doctrine of justification. Within the religions, despite all

experience of the Law. But Christianity has the means to overcome this tendency and find the true resolution of this experience; the religions don't. Thus, even in his later works, Ratschow holds " $\mathrm{Da}$ sehr grundsätzlich die nichtchristlichen Religionen im Modus des Gesetzes dem Christentum als Modus des Evangeliums gegenüberstehen, ist zwar grundsätzlich richtig...* (*Die Möglichkeit«, p. 144). And he still accepts the substance of Luther's definition of the religions as $\#$ Law ( $*$ Die Religionen *, p. 125).

47 Der angefochtene Glaube, p. 286.

48 Ibid., p. 280.

49 Ibid., pp. $286-287$.

50 „Die Möglichkeit«, p. 116. 
their positive content, an understanding of salvation "sola fide" is not possible because of the "solus Christus «, i. e., because of »der christologischen Uberlegung " which Ratschow does not go into.

\section{W. Pannenberg - Example of Historical Nonconfessional Approach}

Pannenberg, just as resolutely as Ratschow, admits the presence of God within the history of religions. The following citation sums up his understanding of this divine presence:

Aus solchen Erwägungen ergibt sich, daß die Religionsgeschichte nicht zureichend verstanden ist, wo sie nur als Geschichte der Vorstellungen und des Verhaltens bestimmter Menschen und Gruppen gilt, die ihrerseits durch rein profane Kategorien beschrieben werden. Sachgemäßer ist die Religionsgeschichte als Geschichte des Erscheinens des in der Struktur des menschlichen Daseins vorausgesetzten göttlichen Gebeimnisses zu verstehen, dessen Wirklichkeit und Eigenart aber im Proze $\beta$ dieser Geschichte selbst auf dem Spiele stehen. ${ }^{31}$

This passage pinpoints the two basic principles of Pannenberg's theology which support his ability to discover God's presence (we can say, God's revelation) within the religions: his antbropology and his concept of history.

Pannenberg's anthropology sees sthe structure of human existence as forcing man to step beyond himself, to be dissatisfied with what he is and can see and therefore to constantly search beyond his own existence and his own particular point in history. Man is essentially Fraglichkeit. He uses his freedom wüber alle vorfindliche Regelung seines Daseins hinauszufragen und hinwegzuschreiten«; he experiences a *chronische Bedürftigkeit* and an *unendliche Angewiesenheit* to a -Gegenüber jenseits aller Welterfahrung*. What distinguishes Pannenberg's anthropological understanding of man as question from other theological antropologies is that he situates this questioning not so much in the individual's experience of himself as in his experience of and relation to the totality of the world and universe. This is seen in the varigated terminology with which Pannenberg expresses man's Fraglichkeit . He describes man as Weltoffenheit. Man searches not only for himself but for a world in which he can find and be himself. .s $^{\text {s }}$ Pannenberg also sees man searching after Wirklichkeit. He is seeking a reality which is not only himself but beyond and more than himself. »Das allgemeine Wirklichkeitsverständnis ist der Ort, wo die Gottesfrage wie die Frage nach dem Menschen auszutragen sind.* ${ }^{54}$ - Man's * Weltoffenheit* and his

51 "Erwägungen zu einer Theologie der Religionsgeschichte«, Grundfragen systematischer Theologie (Göttingen, 1967), p. 290, emphasis mine.

${ }^{32}$ Was ist der Mensch? Die Anthropologie der Gegenwart im Lichte der Theologie (Göttingen, 1962), p. 6, 11.

ss Was ist der Mensch?, p. 10; H. Obayashi, $\gg$ Pannenberg and Troeltsch: History and Religion*, JAAR, 38 (1970) 405.

s4 wirkungen biblischer Gotteserkenntnis auf das abendländische Menschenbild«, Stud. Gen., 15 (1962) 587.

s5 "Hermeneutik und Universalgeschichte*, Grundfragen, p. 109.

56 Was ist der Mensch?, p. 44.

57 Title of Chapter 11 in Was ist der Mensch?, cf. p. 95.

58 "Heilsgeschehen und Geschichte*, Grundfragen, p. 27. 
quest for reality are summed up and can be realized only in an Einheit or Ganzbeit. Man must feel himself part of a unified totality. He (kann) der Ganzheit seines eigenen Lebens nur in Verbindung mit der Ganzheit der Wirklichkeit überhaupt gewiß werden .... $\star^{55} *$ Nur in einer Welt, die eine Einheit ist, kann unser Leben als Ganzes gelingen, kann heil bleiben oder werden. ${ }^{58}$

Pannenberg's anthropology, by its very nature, is related to - is the expression of - his concept of bistory (which, we might say, is both the hallmark and principal point of contention within his theology). Man's Fraglichkeit can be expressed, experienced - and for the scientist, known - only within history. The phrase, $\bowtie$ Der Mensch als Geschichte* illustrates the close connection between anthropology and historicity. ${ }^{57}$ Man can find the reality he seeks - and the unity and totality of this reality - only within history. „Geschichte ist die Wirklichkeit in ihrer Totalität. ${ }^{58}$ For history itself is a totality; it is "Universalgeschichte*, its parts, which include both human and physical nature, form - or are forming - a unity. The fullness of this unity, however, will take shape and be revealed only at the end of history. In the meantime there is a proleptic movement of history towards this final unity, a movement in which the parts are related to each other and progressively clarify each other.

This limited sketch of Pannenberg's anthropology and concept of history becomes clearer and more meaningful when seen as the foundation stone for his theology of religions and for his understanding of God's presence within them: for it is precisely within the religions that man's "Fraglichkeit " and "Weltoffenheit" are expressed and his search for "Wirklichkeit" and "Ganzheit " takes place in a historical process; and it is precisely within the religions that this quest and this historical process shows itself to be inspired by and directed to $n$ the divine mystery " or the "divine reality « 59 "Die in der jeweiligen Erfahrung der Wirklichkeit im Hinblick auf ihre Ganzheit - als Weltbegegnende Macht, die als die einende Einheit jenes Ganzen in Erscheinung tritt, ist die Wirklichkeit, mit der es die Religionen zu tun haben und die - wenn sie sich personhaft manifestiert - allein 'Gott ' heißen darf. «60 The divine reality is the central force and manifesting "Macht " behind all religions. Thus Pannenberg can speak of the "Einheit " of the history of religion, which is nothing else than the Einheit der göttlichen Wirklichkeit selbst «. ${ }^{61}$

But Pannenberg insists that he is not asserting this divine reality and man's search for it as a theological or philosophical principle or a "religious apriori « which he applies to the religions. Rather, he finds this reality and search within the history of the various religions and therefore asserts it. "In solchem tatsächlichen Umgang der Menschen mit dem Geheimnis des Seins (i.e., in the religions), auf das die Struktur ihres Daseins sie verweist, muß sich dessen Wirklichkeit erweisen. In diesem

59 Wie wahr ist das Reden von Gott? «, Evang. Kommentare, November 1971, p. 632;

-Erwägungen*, p. 270.

Bo ,Erwägungen «, pp. 285-286.

61 Ibid., pp. 276-277. 
Sinne kann die Wirklichkeit Gottes oder göttlicher Mächte sich nur durch ihr Widerfabrnis erweisen ... « ${ }^{62}$

We can conclude that this presence of God within the religions, founded in man's existential structure and realized only in an historical process, is a form of universal, divine (supernatural) revelation. Pannenberg states »... daß die Offenbarung Gottes nicht nur irgendwo in der Menschheitsgeschichte als supranaturales Ereignis senkrecht von oben einbreche, sondern das Thema dieser Geschichte selbst ist, die sie im Tiefsten bewegende Macht ${ }^{6 .}{ }^{63}$ "Es ist nicht so, daß die Offenbarung, die Selbstenthüllung Gottes, fertig vom Himmel fällt und am Anfang aller Gotteserkenntnis stehen müßte, weil man sonst gar nichts von Gott wissen könnte. « ${ }^{64}$

3. Thus Pannenberg can insist on the necessity of a positive relation - a dialogue - between Christianty and the religions. For Jesus Christ wist ... die endgültige Offenbarung Gottes nur im Zusammenhang mit der ganzen Geschichte... ${ }^{65}$ This is clear in the New Testament: The »Vollmachtsanspruch Jesu (war) nicht isoliert für sich zum Grunde des Glaubens an die Offenbarung Gottes in Jesus Christus geworden «. Rather it "presupposed « a "Wissen von Gott « both among the Jews and the Gentiles, without which it would have been ineffective, meaningless, »unbegründet «. ${ }^{66}$ Which means for our present situation: "Das ist bis heute das einzige Kriterium (!) für die Wahrheit der Offenbarung Gottes in Jesus von Nazareth, daß sie sich nachträglich immer wieder bewahrheitet an der Erfahrung der Wirklichkeit, in der wir leben. « ${ }^{67}$ From this, Pannenberg draws the explicit and the bold conclusion for the religions: Christianity must prove itself within the history of religions! "Eine Uberprüfung theologischer Aussagen wird sich daher an die Religionen und an die Geschichte ihrer Veränderungen zu halten haben. Denn in den Religionen ist jene Sinntotalität der Wirklichkeit immer schon thematisch, an der die Wahrheit theologischer Aussagen geprüft werden soll.* Through »eine kritische Untersuchung der Religionsgeschichte" in which the theologian as it were suspends his own conviction concerning "die Besonderheit des Christentums und seines Wahrheitsbewußtseins «, the theologian is able "die Besonderheiten der eigenen religiösen Uberlieferung im Zusammenhang der übrigen Religionen zu begründen«. The

\footnotetext{
62 Ibid., pp. 285. cf. also 283, 270.

6s Grundfragen, Vorwort, p. 5.

64 Die Offenbarung Gottes in Jesus von Nazareth«, Theologie und Geschichte, hrsg. von J. M. Robinson and J. B. Cobb, Jr. (Zürich-Stuttgart, 1967), p. 152.

os Ibid., p. 160.

o6 Ibid., p. 143, 141; Offenbarung als Geschichte, p. 136.

67 Die Offenbarung Gottes«, p. 169, emphasis mine.

68 - Wie wahr ist das Reden von Gott? «, pp. 632-633.
} 
result will never be a final, conclusive proof; this comes only at the end of history. But "eine vorläufige Bewährung « is possible. ${ }^{68}$

Pannenberg finds, like Ratschow, the practical example for such a dialogue with the religions in the relation between the Old and New Testaments with their religious worlds. ${ }^{69}$

4. But within this dialogue with the religions, Pannenberg clearly holds to both the finality and the superiority of Christ and his revelation. Christ brings an »endgültige Offenbarung * insofar as he proleptically contains the end of all history which is the source, motivating force and goal of all religions. ${ }^{70}$ Pannenberg explains the two elements which incorporate this prolepsis: "Jesus von Nazareth ist die endgültige Offenbarung Gottes, sofern in ihm das Ende der Geschichte erschienen ist, in seiner eschatologischen Botschaft, wie durch seine Auferweckung von den Toten. ${ }^{71}$ In his message Christ turned men's minds towards the future and assured them that the end of all history is God's and is coming; and by rising from the dead he proved that this message was true and that it already contained the end. Such an understanding of Christ's finality places him both within and beyond the history of religions and seems to offer a valuable insight into the conflict of Christianity's absoluteness and the positive role of the religions. ${ }^{72}$

5. We might conclude that Pannenberg's »theology of the religions presents a truly positive final verdict on the non-Christian world. - Yet, looking deeper, we find many of the same unclarities and even contradictions which we noted in Ratschow's views. From other aspects of Pannenberg's approach to the religions, one has the impression that in the final analysis, the religions cannot break out of their Fraglichkeit, that all they have are questions, that they cannot really know God sufficiently to receive the salvation he effected in Christ. This impression rests on three overlapping considerations:

a) Pannenberg's understanding of history as receiving its meaning only at the end implies that the presence of God - his revelation although felt and experienced throughout history can be understood and seen as what it is only at the end, or, only in the "prolepsis " or anticipation of this end in Jesus Christ. Thus, when Pannenberg speaks of the revelation of God as the theme and "im Tiefsten bewegende Macht « of all history, he immediately adds that we can speak "sinnvoll von einer Offenbarung Gottes... nur im Hinblick auf das Ganze der Wirklichkeit" and this "Ganze" is seen only "von einem Ende alles Geschehens

60 Die Offenbarung Gottes«, pp. 139-140; Offenbarung als Geschichte, pp. 97-98; cf. also Die Aufnahme des philosophischen Gottesbegriffs als dogmatisches Problem der frühchristlichen Theologie «, Grundfragen, pp. 296-346.

70 Die Offenbarung Gottes«, p. 159; cf. also p. 167.

71 Ibid., p. 160, emphasis mine.

72 .Erwägungen «, pp. 291-292. 
her «. The »end" therefore has »konstitutive Bedeutung ... für die Frage der Gotteserkenntnis «. ${ }^{73}$ This means, apparently, that there is no real "Gotteserkenntnis " before the end, or before the anticipation of the end in Jesus Christ. ${ }^{74}$ And since Pannenberg identifies revelation and salvation, this means that salvation is truly possible only at the end, i. e., only in Christ's revelation. ${ }^{75}$ For the religions this seems to imply that while they experience God, they do not really know him or come into possession of him. God as the "Einheit " of all religions can be seen only in Christ and Christinaity. "... erst daraufhin läßt sich von einer allgemeinen Religionsgeschichte der Menschheit sprechen. Die Einheit der Religionsgeschichte ist also nicht an ihren Anfängen, sondern eher an ihrem Ende zu suchen. «76

b) If we can speak of true revelation only at the end, in Jesus Christ, then the religions apparently are confined within the bonds of their Fraglichkeit. And it seems that, of themselves, they cannot even understand their own searching or the contents of their own questions. Pannenberg confronts this question explicitly:

Das Problem liegt nur darin, ob die Fraglichkeit des Daseins sich erst von der Antwort in der Offenbarung Gottes her enthüllt, oder ob sie allgemein zugänglich ist. Nicht nur Bultmann, auch Tillich und Ebeling möchten an dem für Barth entscheidenden Gesichtspunkt festhalten, daß die Fraglichkeit des menschlichen Daseins und aller endlichen Wirklichkeit überhaupt erst von der göttlichen Antwort her in ihrem wahren Sinn zu verstehen ist. ${ }^{77}$

Pannenberg agrees basically with this position, although, with Tillich and against Barth, he holds that the "Fraglichkeit " in its unclarity still has an apologetic meaning (i.e., as an "Anknüpfungspunkt «). ${ }^{78}$ Yet if man in his religions has only questions - which are not really understood - can we say he really knows God? This problem becomes all the more pressing when we see that Pannenberg qualifies the Wissen von Gott « in the religions by adding that its »eigentliche Wirklichkeit (wird) erst durch Jesus enthüllt«. »Am Anfang steht... - bildlich gesprochen - die Verhüllung (velatio) Gottes, und erst am Ende wird die Hülle beseitigt, erfolgt die revelatio." In this "Verhüllung " God is indeed "erfahren «, but only in Christ is God's "Selbstenthüllung" given; only in Christ is he known.

73 Grundfragen, pp. 5-6.

74 Offenbarung als Geschichte, p. 103; cf. also, Mann, Theogonische Tage, p.695, footnote 18.

75 Die Selbstenthüllung Gottes aber ist das Heil für die Menschen, weil nur in der Nähe Gottes, in Gemeinschaft mit Gott, das Dasein der Menschen Erfüllung findet.* -Die Offenbarung Gottes«, p. 153. The term «Selbstenthüllung is applied here to the final revelation, i. e., in Christ.

76 „Erwägungen «, p. 275, cf. also p. 264.

77 „Die Frage nach Gott«, p. 371.

78 Ibid., p. 386. 
Franz Konrad's critique, therefore, would seem to be correct: according to Pannenberg, man before Christ's coming can have only a questioning experience of God; answers cannot be achieved. The first relation of Christ's revelation to the non-Christian therefore is a negative one. ${ }^{80}$

c) Further, in a terminology reminiscent of Barth, Pannenberg states that the religions corrupt their experience and knowledge of God, "...daß in ihnen das Widerfahrnis (of God), auf dem sie beruhen, zugleich verkehrt worden ist dadurch, daß die Mächte, die hier als Wirklichkeit gelten, in Wahrheit noch zum Bereich des Endlichen gehören « ${ }^{81}$ The "Selbstbekundungen des wahren Gottes" in them is "wie Paulus sagt, in Ungerechtigkeit niedergehalten ...«82 The knowledge of God in the religions is »durch mancherlei Verkehrung verdunkelt. Sie verwechseln die Gestalt des Schöpfers mit der der Geschöpfe". (Röm.1, $18 \mathrm{ff}$. ${ }^{83}$ The religions, therefore, not only cannot fully grasp the mystery of God, they also misuse it. "Freilich lassen die Religionen in der Tat ein eigentümliches Widerstreben der Menschen gegen die Unendlichkeit (Nichtendlichkeit) des göttlichen Geheimnisses beobachten ... Die außerchristlichen Religionen nahmen das Erscheinen des göttlichen Geheimnisses nur in gebrochener Weise wahr, weil sie sich ihren eigenen Wandlungen, ihrer eigenen Geschichte verschlossen. ${ }^{84}$ - Any theologian would admit that in many religions this corruption of the knowledge of God is a fact. But Pannenberg here seems to assert that this corruption must take place, that it is unavoidable.

We must note that Pannenberg, in his negative statements on the religions, does not harshly brand them as »works « or the Law or as man's attempts to save himself. The reservations and unclarities within his position do not stem, explicitly, from the traditional doctrine of justification, i. e., that God leads men to the "sola fide" (which means to true revelation) only "solo Christo ". And yet, these reservations are founded on his Christology - on his understanding of Christ as the sole or historically limited pprolepsise in which God reveals the vend" - and that means, in which God brings men to salvation. Therefore, despite Pannenberg's positive anthropological approach to the religions, despite his new historical-phenomenological method, we still can confront him with questions which, we feel, are essential to a full theological evaluation of the religions: Can the religions bring their followers to a

79 „Die Offenbarung Gottes*, pp. 152-153; cf. also p. 160.

80 Der Offenbarungsbegriff in der evangelischen Theologie (München, 1971), p. 237, also p. 368; cf. Obayashi, p. 417.

81 Die Frage nach Gott*, pp. 380-381.

82 Ibid., p. 386.

83 -Die Offenbarung Gottes«, p. 144.

84 „Erwägungen*, p. 293. 
salvific encounter with God? Do they contain more than just questions and searching? Can we »dialogue " with them as something more than a "negative preparation « for the Gospel? Pannenberg seems to neglect clear answers to these questions.

\section{-Opinio Communis* within Systematic Theology}

1. Fritzsche, Ratschow and Pannenberg reflect what we feel is the "opinio communis concerning the non-Christian religions as found among present-day German-speaking Protestant theologians. The general consensus of other theologians does not go beyond these three examples (certainly not beyond Pannenberg, most of them remaining close to either Fritzsche or Ratschow). We shall outline now a few examples of this "opinio communis «. In so doing we shall try to avoid the danger of brevity becoming over-simplification.

2. Peter Brunner ${ }^{85}$ - His understanding of the religions is determined by the doctrine of the Law. The religions contain a form of revelation in that, through creation, they receive a "Strahl seiner gottheitlichen Glorie". Yet they cannot come to a true knowledge of God's will and law; the real God is not revealed to them. In the religions we find a »Urverweigerung gegenüber der suchenden, liebenden Hand Gottes «. The religions remain shackled in »der Kreatürlichkeit der Kreatur «. Why? The reason appears to be the "solus Christus «: only in Christ is the real God revealed; only in him can we understand and properly use the Law. Only in Christ do we realize that mankind outside of him is captured in an absolute "Verlorenheit «. ${ }^{86}$

3. Wolfgang Trillhaas ${ }^{87}$ - Admitting that "eine theologische Lehre von der Religion... kaum je innerhalb der protestantischen Dogmatik versucht worden ist ", he also insists that such a teaching on the religions can be established "nur von einer Lehre vom Gesetz aus «. Yet his application of the "Law « to the religions is not as negative as $\mathrm{P}$. Brunner's. Trillhaas argues that the religions spring from the experience of the mystery behind the world and from the attempt to establish a relation of security with this mystery. Yet he does not allow this effort to succeed (just as the Law can never of itself lead to the Gospel). The religions contain only "Fragen ", "Erwarten ", »Vorverständnis«. He explicitly states that they cannot be $a *$ Weg des Heiles «. Rather, they are meant

85 Professor Emeritus of Systematic Theology at the University of Heidelberg.

88 Pro Ecclesia I (Berlin, 1962), pp. 100-105. - In their dristomonistic understanding of revelation, Otto Weber and Albrecht Peters offer this same sharply negative verdict on the religions. Cf. Weber, Grundriß der Dogmatik I (Neukirchen, 1955), pp. 226-237; Peters, ^Die Frage nach Gott«, Fuldaer Hefte 17 (Berlin, 1967), pp. 80, 92, 95-100.

87 Professor of Systematic Theology, University of Göttingen. 
for the "Erhaltung " of fallen man. At the most, they can be considered »ein Pädagoge auf Christus hin « ${ }^{88}$

4. August Kimme ${ }^{89}-\mathrm{He}$ attempts a theology of the religions based on the doctrine of the Trinity. Through "appropriation « we can admit an activity of God the Creator "unter Mitwirkung seines ewigen Sohnes « in the hearts of the non-Christians which prepares them for an encounter with Christ. ${ }^{90}$ And yet, Kimme's outlook remains basically negative. Revelation in creation is infralapsarisch $\ll .{ }^{91}$ It cannot escape the infection of sin; man in his religions must misuse this revelation; for the saving Logos and the saving Spirit are to be found only in Christ. "Denn die Heilsbotschaft von dem dreieinigen Gott und dem einzig rettenden Namen Jesus Christus schließt eine positive Darstellung und Wertung anderer Heilswege und Glaubensweisen radikal aus. «92 Kimme can even distinguish the "außerchristologische Regiment Gottes des Schöpfers " in the religions and the "trinitarische Regnum Christi in the Gospel. Salvation is found only in the "Regnum Christi «. He explicitly states that this means "Extra ecclesiam nulla salus «. ${ }^{93}$ - The religions, therefore, under God the Creator but without Christ the Savior, are, at the most, a negative preparation for Christianity.

6. Willy Böld ${ }^{94}$ - While stressing the necessity of dialoguing with the religions, Böld maintains that this dialogue must be built on the principle of Christianity's "Absolutheit « which in turn is determined by his interpretation of the "solus Christus «: because God's truth was expressed in the person of Christ and thus becomes personal truth, this truth becomes not only »letztgültig " and »allgemeingültig" but also "alleingültig «.95 To preserve this understanding of Christianity's "Alleinguiltigkeit« is the role of the Reformational "dreifachen Solus: ... Solus Christus ... Sola Scriptura ... Sola Fide«. It means that truth can be found only in the person of Christ and in the "personalen Akt火 of faith in the »Christuswahrheit". Böld warns against relativizing

\$* Wrillhaas, Dogmatik (Berlin, 1962), pp. 226-231; cf. also id., Religionsphilosophie (Berlin, 1972), which appeared too late to be evaluated in this context.

${ }^{89}$ As Director of the «Leipziger Mission «, Kimme's views might well be listed also among the mission-theologians below. But because his evaluation of the religions is built predominantly on a systematic-trinitarian foundation, we have deemed it more logical to present it here.

90 A. Kimme, Universalität und Exklusivität der christlichen Heilsbotschaft. Ein dogmatischer Versuch zum Thema, Theologie der Religionen 16 (Berlin, 1966), p. 180.

21 Ibid., pp. 169-171.

92 Ibid., p. 166; cf. also pp. $146-152,155,160-161$.

93 Ibid., pp. 172, 176.

94 Professor at the $\rtimes$ Pädagogische Hochschule des Saarlandes*, Saarbrücken.

95 W. Böld, Das Problem der Absolutheit des christlichen Heilsweges«, Kirche in der außerchristlichen Welt (Regensburg, 1967), pp. 32-35, 37-40. 
Christ by setting him up as the expression or summing-up of truth in other philosophical systems or religions. ${ }^{96}$ This means that the role of the religions is only to point out "die noch ungelöste und im Grunde unlösbar scheinende Schicksalsproblematik der Menschheitsgeschichte «, ${ }^{97}$ - i. e., a negative role.

7. Wilhelm Dantine ${ }^{98}$ - Describing the formula "sola fide « as the "wesentlichen Beitrag " which Protestantism must make in the ecumenical dialogue with the religions, Dantine seems to offer a much more positive interpretation of this formula. He not only recognizes God's presence in all religions in the form of an "ontological thirst «" ${ }^{99}$ but also admits that many religions have come to a clear understanding of the "sola fide", even clearer than many synergistic brands of Christianity. $\mathrm{He}$ singles out Amida Buddhism and Bhakti mysticism. ${ }^{100}$ But an essential difference remains - because of the "solus Christus «, i. e., because of the "christologische Fundierung des ssola fide«", which the religions do not have. He interprets this christological foundation as »die forensische Dimension der christlichen Sola-Fide-Lehre«. "Der Glaube wird nie davon ablassen, zu bezeugen, daß solche Freiheit und Gewißheit an den Namen Jesus Christus gebunden ist. Denn das ssola fider hat seine eigentümliche Fundierung im Kreuzweg Christi, d.h. darin, daß Jesus von Nazareth ... sich dem Gericht unterwarf, in die forensische Situation eintrat, in der der Mensch stets coram deo existiert, und sich ihr auslieferte. «101 This would imply that the religions cannot understand the "sola fide", that they cannot attain the salvation built on Christ's resolution of the forensic situation. The most Dantine can say of such doctrines is that they are "not far from the kingdom of God «. ${ }^{102}$ The religions remain within the unredeemed realm of the Law. ${ }^{103}$

8. Ulrich Mann ${ }^{104}$ (his position before 1970) - Just as clearly as Ratschow and Pannenberg, Mann affirms a genuine revelation within the religions. He even favors Hegel's understanding of religious history "als Entwicklung der absoluten Religion « in which "Gott sich in der Geschichtlichkeit seiner selbst bewußt wird und sich eben darin bewußt

\footnotetext{
96 Ibid., pp. 43-47.

97 Ibid., p. 32.

98 Professor of Systematic Theology at the University of Vienna.

99 -Die dristologische Fundierung des SOLA FIDE. Dogmatische Uberlegungen im Horizont von Religionserfahrung und Religionskritik«, Der Christliche Glaube und die Religionen, hrsg. von C. H. Ratschow (Berlin, 1967), pp. 30-33.

100 Ibid., pp. 37, 39.

101 Ibid., p. 38.

102 Ibid., p. 39.

103 Ibid., pp. 36-37.

104 Professor of Systematic Theology and Philosophy of Religion at the University of Saarbrücken.
} 
macht «. ${ }^{105}$ "Die Geschichte der Religion ist die Geschichte der Gottesoffenbarung. «106 Yet he also insists that for a Lutheran theology the doctrine of the Law is »eine Schlüsselstelle ... für das theologische Verständnis der Religion « - which means: "Das Gesetz führt nicht zum Heil, denn unter dem Gesetz versucht der Mensch sich der Offenbarung Gottes zu bemächtigen." This implies that while revelation remains in the religions »diese Offenbarung ist immer auch durch Menschenwerk und Menschenbeiwerk verfälscht «. The most Mann can conclude ist that »wo also das Gesetz zum Tode führt, da ist zugleich eine dialektisch zu verstehende äußerste Nähe zum Heil in Christus gegeben. Eine Nähe, wenngleich keine Identität! Es gibt wirklich ein $>$ Nichtfernsein vom Reiche Gottes« (Mk. 12,34) «. ${ }^{107}$ But the religions can never find this God, his kingdom and salvation; they can never attain any "real answers « and are left with only questions.

Interestingly and somewhat enigmatically, Mann, in his recent works, Theogonische Tage (1970) und Das Christentum als Absolute Religion (1970) makes a radical shift in the method and conclusions of his theology of the religions. Drawing heavily on the depth psychology of C.G. Jung and interpreting this history of religions as the development of divinely-instilled "archtypes", he expressly admits not only revelation but also salvation - not only the Law but the Gospel - within the religions! It would take a special study to weigh and sift out theology and psychology in Mann's new approach; yet it remains one of the most challenging attempts at a theology of the religions among present-day German Protestant theologians.

9. What seems to be the "opinio communis « of these systematic theologians was reflected quite clearly in the discussions and reports of the 18th and 19th Meetings of the "Theologischen Konvent Augsburgischen Bekenntnisses " (1962-1963). ${ }^{108}$ Although the participants openly called for a more positive encounter with the religions and rejected a rigid Christomonism ${ }^{109}$ they also resolutely opposed the "cosmic Christology " of New Delhi, ${ }^{110}$ unanimously rejected the teaching of the "logos spermatikos in the religions; and asked: "Kann wirklich vom Wirken Christi und vom Wirken des Heiligen Geistes in den Religionen gesprochen werden? Ist hierbei nicht die Trinitätslehre in einer entscheidenden Weise verfälscht? «111 The religions must be interpreted in a twofold

105 Theologie und Religionsgeschichte", Luth. Monatshefte, 1964, p. 252, cf. also p. 259.

108 „Religion als theologisches Problem *, Christentum und Religion (Regensburg, 1966), pp. 88-89.

107 "Theologie und Religionsgeschichte «, p. 255, cf. also p. 261.

108 Cf. Reports by P. Reinhardt, Fuldaer Hefte 16, op. cit., pp. 181-186; E. Rose, op. cit., pp. $187-198$.

109 Rose, p. 194.

110 Especially as in J. Sittler's paper, "Zur Einheit berufen*, in Neu-Delhi, 1961, hrsg. von W. A. Visser't Hooft (Stuttgart, 1962), pp. 512-523.

111 Reinhardt, pp. 184-185. 
(and essentially negative) dialectic as $\gg$ Ausdruck der frommen Selbstbehauptung des Menschen gegenüber Gott « and as ways in which God »die Menschen in diesen Religionen auf (bewahrt) für die Begegnung mit Christus «. ${ }^{112}$ Any final verdict on the religions must bear in mind the insistence of the "Reformers «: "Errettung vor Gott im Jüngsten Gericht gibt es nur durch den Glauben an Christus, und dieser Glaube kommt aus dem Wort... der Fluch des Gesetzes gilt allen Menschen, die Gnadenzusage aber nur den Christusgläubigen. «113 - Again, any positive contents in the religions are overshadowed by the "sola fide" and "solus Christus«.

\section{•Opinio Communis* within Mission-Theology}

1. Examples drawn from the views of present-day German Protestant mission-theologians concerning the religions present pretty much the same picture as those of the systematic theologians. The missiologists, as might be expected, show more of a determined effort to wencounter " the religions and in general they work with more of a factual knowledge of non-Christian faiths. But their final evaluation follows, for the most part, that of Hendrik Kraemer, the Dutch missiologist who, perhaps more than any other thinker, molded Protestant mission theology during the first half of this century:114 they reject the extreme tones of Barth's "No " to the religions, seek to communicate with them, but do not really arrive at a counter-position to Barth; the religions remain "man's works - within the precincts of the Law - a negative preparation for Christianity.

2. Gerhard Rosenkranz ${ }^{\mathbf{1 1 5}}$ - Here again we hear a sincere plea for dialogue with the religions, ${ }^{116}$ and for a thorough, phenomenological knowledge of them. ${ }^{117}$ Rosenkranz also clearly recognizes a presence of God within the religions and is against considering them only as $»$ Entartung «. ${ }^{118}$ Yet with equal vigor he is opposed to speaking about a real

112 Ibid., p. 182.

113 Rose, p. 197.

114 Hallencreutz, New Approaches, p. 27; J. Aagaard, Revelation and Religion *, StTh, 14 (1960) 163; A. C. Bouquet, The Christian Faith and Non-Christian Religions (Digswell Place, 1958), p. 398.

115 Professor Emeritus of Missiology and Ecumenical Theology at the University of Tübingen.

116 Rosenkranz, Der christlidhe Glaube angesidhts der Weltreligionen (Bern, 1967), pp. 47-54, 214, $283-291$.

117 - Wege und Grenzen des religionswissenschaftlichen Erkennens«, Religionswissenschaft und Theologie, Aufsätze zur evangelischen Religionskunde (München, 1964), pp. 28, 35.

118 Der dristliche Glaube, p. 215; id., „Was müssen wir heute unter Absolutheit des Christentums verstehen?«, ZThK, 51 (1954) 111-113. 
revelation within the religious world. Such a doctrine, based on the concept of the "logos spermatikos «, is "ein lebensgefährliches Symptom* for a theology of religions. ${ }^{119}$ Rosenkranz therefore accepts "die Kritik Feuerbachs «: the religions are a purely human affair in which man seeks self-redemption and self-glorification. The foundation for such a verdict is clearly Rosenkranz' understanding of Christ and justification. Only here do we find revelation and salvation. ${ }^{120}$ Because Christ proclaimed the "Word" of "sola fide" it is "ein Wort radikal anderer Art « which leaves the world of religions under »der Decke der Selbsterlösung «, in "grenzenloser Verlorenheit und Verlassenheit «. ${ }^{121}$ The only possible ground of dialogue with them is to be found in the "Existenzerfahrung " - i. e., the religions' failing attempts to answer the question of "des Leidens, der Not, der Schuld, des Todes . .... ${ }^{122}$

3. Walter Holsten ${ }^{123}$ - In his efforts to establish comparative religions as a theological discipline ${ }^{124}$ Holsten renders even clearer the central place which the doctrine of justification is to hold in a theological understanding of the religions. Presupposing that every science needs a point of reference, he proposes "als gemeinsame Voraussetzung der Religionswissenschaft « the Christian Kerygma, i. e., "das Kerygma nach reformatorischem Verständnis" - man's lost state and salvation only through faith and grace in Christ. The religions are therefore seen as various expressions of the same human condition: man's need of God's intervention in "sola fide" and "solus Christus «. ${ }^{125}$ This "presupposition", which excludes any possibility of revelation or salvation in the religions and which provides "eine prinzipielle Erledigung " for "das viel verhandelte Problem der Anknüpfung ", ${ }^{126}$ is the basis on which Holsten also seeks to carry on a dialogue with the religions - a dialogue, we feel, in which the religions have nothing more than a negative contribution to make.

4. Peter Beyerhaus ${ }^{127}$ - Seeking after a theology of the religions which balances the traditional approaches of continuity or discontinuity Beverhaus affirms that it is necessary das sola fide und solus Christus

119 »Wege und Grenzen «, p. 21; Absolutheit «, pp. 114-115.

120 Der christliche Glaube, p. 116. ^Absolutheit«, p. 119; "Wege und Grenzen«, p. 34 bis 36.

121 Der christliche Glaube, pp. 278, 301-302.

122 Der christliche Glaube, p. 291.

${ }_{123}$ Professor of Missiology at the University of Mainz.

124 Das Kerygma und der Mensch. Einführung in die Religions- und Missionswissenschaft (München, 1953), pp. 9-10, 34-38, 85.

125 Ibid., pp. $43-55$.

126 Ibid., pp. 86-89.

127 Professor of Missiology and Ecumenical Theology at the University of Tübingen. 
im reformatorischen Sinne neu zu bezeugen « ${ }^{128}$ This demands a "tripolares Religionsverständnis " in which the religions show a "Bezogenheit auf Gott ", "das Bemühen Gottes « and "den Einflußbereich der dämonischen Mächte «. ${ }^{129}$ The practical consequences of such an understanding: the religions can never be "ways of salvation "; they are caught up in a "sündige Abwandlung der religiösen Aufgabe«; they are "gezwungen aus Gott gegen Gott zu leben ... immer weiter von Gott weg und damit in den Streit wider Gott «; they never can fully lose their quality as »Gegner" to the Gospel. ${ }^{130}$ - Their role, so it seems, turns out to be basically negative.

5. Georg F. Vicedom ${ }^{131}$ - In Vicedom we find a much clearer and more personal plea to understand the religions, to take them seriously and to avoid all hasty condemnations deriving from »einer maßlosen Uberheblichkeit der Christen «. ${ }^{132} \mathrm{He}$ acknowledges a revelation within and as the origin of the religions and finds in them »die volle Würde der Gottesebenbildlichkeit «. ${ }^{133}$ And yet, because of his understanding of true revelation and salvation only in Christ, he places the religions within the "Erhaltungsordnung Gottes « as opposed to the order of salvation. ${ }^{134}$ »... dürfen wir mindestens so viel sagen, daß er (God) durch die Religionen die Erlösungssehnsucht in den Menschen wachgehalten hat ...«135 The religions, however, have "das Gottesverhältnis so umgekehrt, daß sie anderen Mächten und nicht mehr Gott die Ehre geben «. ${ }^{136}$ What they do not have and cannot understand and what Christianity brings as "etwas radikal Neues « is "die Erlösung aus Gnaden «. ${ }^{137}$ Christianity must therefore also be "Kritik und Ende des falschen Glaubens" in the religions and bring them "eine neue Gottesgemeinschaft " which is given in faith in Christ. ${ }^{138}$

128 * Zur Theologie der Religionen im Protestantismus*, KuD, 15 (1969) 101.

129 Ibid., p. 103.

130 Religionen und Evangelium, Kontinuität oder Diskontinuität«, EMM, 11 (1967) $131-132$.

131 Professor of Missiology at the Augustana-Hochschule, Neuendettelsau.

192 Jesus Christus und die Religionen der Welt (Wuppertal, 1966), p. 86.

133 Ibid., pp. 64-72, 86, 141, 150; cf. also, id., „Die Religionen in der Sicht von NeuDelhi *, in Fuldaer Hefte 16, p. 22.

134 Jesus Christus und die Religionen, p. 150.

135 Ibid., p. 141.

136 Ibid., p. 150.

137 Ibid., p. 151 ; Die Religionen in der Sicht von Neu-Delhi«, p. 21.

138 Jesus Christus und die Religionen, p. 152. Yet Vicedom, in his Christian concern, feels that on the basis of I Tim. 4, 10 we cannot exclude salvation within the religions. But neither can we say just how it takes place. Here he states that salvation is possible for the individual, without implying that the religions themselves

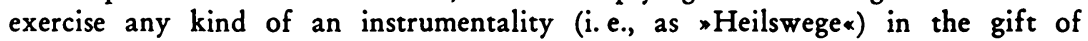
justification; cf. ibid., p. 142. 
6. Hans-Werner Gensichen ${ }^{139}$ - Even more resolutely than Vicedom, he calls for a new, more positive approach to the religions, abandonment of the old Discontinuity- Continuity pattern and a dialogue in which the religions are respected and thoroughly known. ${ }^{140}$ Yet, his own theological position within this dialogue is not always perfectly clear. He urges direct encounter, especially in the missions, through simple witnessing, without asking what is the salvific state of the non-Christians or whether they offer "Anknüpfungspunkte «.141 And still, when he does touch on a theological judgment of the religions, he seems to prefer Dantine's approach from justification »sola fide « and Ratschow's dialectic of Law and Gospel. ${ }^{142}$ He himself can remark that »die guten Werke " of the religions are always "ambivalent und vermögen den rechtfertigenden Glauben nicht zu ersetzen ", that the Gospel is not only "Herausforderung " but also "Krisis aller Religionen «, ${ }^{143}$ »daß für die Menschheit in keinem anderen Heil ist als in Jesus Christus, und daß nur im Kraftfeld dieses Heils die Solidarität der Sünde von der Solidarität des Glaubens überboten wird «. ${ }^{144}$ But just how far does this "Kraftfeld « extend? Can the religions find salvation? Or do they remain within the realm of the Law? - Such questions, we feel, are not necessarily answered negatively but neither are they answered clearly.

7. Horst Bürkle ${ }^{145}$ - He represents one of the boldest calls for dialogue and one of the most positive theological approaches to the religions which we find among contemporary Protestant mission-theologians in Germany. To an extent he stands as an exception to the "opinio communis «. This is seen especially in his general approval of the "cosmic Christology « as proposed by the young mission Church, mainly in India, ${ }^{146}$ and in his argument that "Jesus Christus... als Herr der Geschichte" participates in the movement of all history and makes all history and all religions theologically relevant. ${ }^{147}$ Yet, in our opinion, Bürkle does not fully respond to the objections he himself lists against a »cosmic Christology «; i. e., that it does not do justice to the traditional

130 Professor of Missiology and Comparative Religions, University of Heidelberg.

140 *Wirklichkeit und Wahrheit der Religionen *, Luth. Monatshefte, February 1968, pp. 41-43; *Die christliche Mission «, pp. 66-72.

141 Die christliche Mission *, pp. 72-79.

142 *Wirklichkeit und Wahrheit «, pp. 96-97.

143 „Der Synkretismus als Frage an die Christenheit heute«, EMZ 23 (1966) 61, 64; cf. also p. 65 where he refers to the new religions as $₫$ theologisch beurteilt, Werke des Gesetzes«.

144 „Herausforderung $\propto$, p. 86.

145 Professor of Missiology and Comparative Religions at the University of München.

146 ॠDie Frage nach dem ,kosmischen Christus als Beispiel einer ökumenisch orientierten Theologie «, KuD, 11 (1965) 103-115, esp. 110-113.

147 Zum Problem des Dialogs*, Jabrbuch Evangelischer Mission, 1968, pp. 42-43. 
doctrine of justification and the reality of $\sin$ in the religions. ${ }^{148}$ Further, one has the impression that he interprets God's and Jesus Christ's presence in the religious world only insofar as God is bringing about »die Voraussetzungen für sein (the non-Christian's) Christwerden «, ${ }^{149}$ or, in the terminology frequently employed by Bürkle, only insofar as God is providing "Auslegungsmittel for the Gospel. ${ }^{150}$ How positive is this "Auslegungsmittel «? Can the religions, before they encounter Christ, overcome sin and find salvation through it? Is God's presence in them only "preparatory" or can it also be salvific? Again, we feel that such questions are not clearly confronted. ${ }^{151}$

8. Der Deutsche Evangelische Missions-Tag together with "Die Arbeitsgemeinschaft Evangelischer Missionen «, in their Meeting in September 1966, offer a particularly sharp formulation of the wopinio communis « of mission theologians. It was expressed as part of their commentary on "Nostra Aetate ", Vatican II's Declaration on the NonChristian Religions. ${ }^{152}$ They flatly state that they cannot accept Vatican II's positive evaluation of the religions because it is not consistent with the "Evangelium von der Rechtfertigung des Sünders. «153 Loyal to the doctrine of justification, they state: "So finden wir auch nirgends in den nachchristlichen Religionen eine besondere Offenheit für das Evangelium." There can be no "Anknüpfung an die Religiosität« of the religions. Rather there must be a clear $n$ Bruch ${ }^{154}$ - A similar attitude was voiced in the $\gg$ Frankfurter Erklärung zur Grundlagenkrise der Mission «: "(Wir) verwerfen ... die Irrlehre, als ob die Religionen und Weltanschauungen auch Heilswege neben dem Christusglauben seien.* The statement insists on the necessity of conversion and sees dialogue with the religions as wallein eine gute Form missionarischer Anknüpfung. ${ }^{155}$ - Therefore: absolutely no salvation in the religions; at the most, a negative preparation for the Gospel.

148 Die Frage«, p. 107.

140 Bürkle, «Zum Problem«, p. 42.

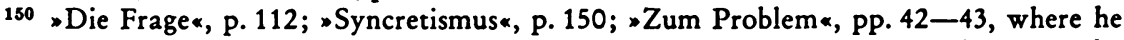
speaks of "Auslegungsprinzip . And in this context he proposes dialogue in the sense of H. Kraemer! cf. „Syncretismus*, p. 149.

151 Holding more or less the same *progressive position as Bürkle is Werner Kohler - Towards a Theology of Religions«, Japanese Religions, 4. 3. 1966, pp. 33-34; -Theologie und Religion«, Glaube, Geist, Geschichte. Festschrift für Ernst Benz zum 60. Geburtstag, hrsg. von G. Müller und W. Zeller (Leiden, 1967), pp. 462-463; id., "Kirche und Mission im Umdenken «, EvTh, 30 (1970) 390-391.

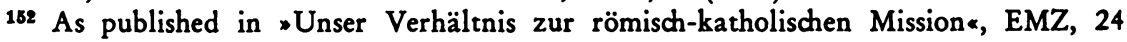
(1967) 33-38.

153 Ibid., p. 36.

154 Ibid., p. 37.

155 Released by the *Theologisches Konvent*, March 4, 1970, Thesis 6, as quoted in epd Dokumentation 35/70, p.5. Cf. M. Mildenberger, -Dialogfähige Theologie«, OR, 21 (1972) 47. 


\section{An Overall Negative Verdict - Impediment to Dialogue?}

Our brief analysis of three representative contemporary Protestant theologians - Fritzsche, Ratschow and Pannenberg - and our survey of what seems to be the "opinio communis « of present-day systematic and mission theologians might be summed up in the following points:

a) All of the theologians we studied show the clear resolve to abandon or avoid the extreme negativism of Barth's early position, and at the same time not to fall into a relativistic watering down of the Gospel.

b) They all call for a new and serious confrontation with the religions, a dialogue with them. Most of the theologians also emphasize the need for a sound, factual study and knowledge of the science of religions.

c) In their attempts to come to a theology of the religions, they all hold to what we may call some form of revelation within them, even though many rule out or avoid such terminology (Fritzsche, Ratschow). For all of them, God is somehow present in the religions - in a Godinspired "Fragen nach Gott " (Fritzsche) in his "Hervortreten" (Ratschow), in the divine "Wirklichkeit " (Pannenberg), in a "Strahl gottheitlicher Glorie" (P. Brunner), in the activity of the "Schöpfer" (Kimme), as an "ontological thirst" (Dantine), as a "Bezogenheit auf Gott « (Beyerhaus). And this divine presence or revelation must have a definite meaning within a theology of the religions.

d) Yet in all these cases, in explicit reference to the doctrine of justification or to the unique salvific role of Christ there is a negative attitude concerning the possibility of salvation in or through the religions:

- either salvation is expressly ruled out and the religions are considered to be works of sin and attempts at self-redemption (Fritzsche, P. Brunner, Kimme, Rosenkranz, Holsten, Beyerhaus)

- or without expressly condemning the religions, it is implied that they cannot find salvation insofar as they do not understand the "sola fide" or cannot find satisfying answers. (Ratschow, Pannenberg, Trillhaas, Böld, Dantine, Mann [in early stage], Vicedom)

- or the question of possible salvation through the religions is passed over or not given a clear answer. (Gensichen, Bürkle)

e) The result of this express or indirect denial of the possibility of salvation within the religions is that the revelation or presence of God within the religions is either:

- practically denied: the possibility of knowing God never becomes an actuality, or the "true " God is never known.

- severely limited: the non-Christian always misuses this revelation and thus renders it ineffective; or its true contents can be known 
only "von Christus her «; or it remains in the realm of searching and questioning and can never find any satisfying answers.

Does not all this mean:

a) The religions, interpreted within the categories of the Law, can prepare the non-Christians for Christ but they can never be instruments in bringing them salvation or true encounter with God?

b) Their positive elements or their »truth « amount to only a searching and questioning but never to a finding of any real answers, i. e., to a finding of God and salvation?

c) Their role of preparing for Christ is therefore basically a negative one: only to reveal man's need, his searching, and his sinfulness?

d) In our dialogue with the religions we must insist that only we who have Christ have the real answers - i.e., answers which bring salvation?

But is all this a basis on which we can carry on an effective dialogue with the non-Christian world? 